\title{
Repeated apnea-induced contraction of the spleen in cyclists does not enhance performance in a subsequent time-trial
}

\author{
Billy Sperlich • Christoph Zinner • Roman Pfister • \\ Hans-Christer Holmberg • Guido Michels
}

Received: 19 May 2014 / Accepted: 15 September 2014 / Published online: 27 September 2014

(C) Springer-Verlag Berlin Heidelberg 2014

\begin{abstract}
Purpose Splenic contraction induced by repeated apneas has been shown to increase oxygen availability. Our aim was to determine whether repeated maximal voluntary apnea enhances the performance of cyclists in a subsequent 4-km time trial.

Methods Seven male cyclists [age: $27.1 \pm 2.1$ years; height: $182 \pm 8 \mathrm{~cm}$; body mass: $74.8 \pm 9.2 \mathrm{~kg}$; peak oxygen uptake: $56.9 \pm 6.6 \mathrm{~mL} \mathrm{~min}^{-1} \mathrm{~kg}^{-1}$ (mean $\pm \mathrm{SD}$ )] performed a $4-\mathrm{km}$ time trial on an ergometer with and without four prior maximal bouts of apnea interspersed with 2 min of recovery.

Results The average power output during the time trial was similar with $(293 \pm 48 \mathrm{~W})$ and without $(305 \pm 42 \mathrm{~W})$ prior apnea $(P=0.11, d=0.27)$. The spleen was reduced in size after the fourth bout of apnea $(-12.4 \pm 9.0 \%)$, as well as one $(-36.6 \pm 10.3 \%)$ and $10 \mathrm{~min}(-19.5 \pm 17.9 \%)$ after the time trial, while with normal breathing the spleen was smaller one $(-35.0 \pm 11.3 \%)$ and $10 \mathrm{~min}$ $(-23.4 \pm 19.7 \%)$ after the time trial. Heart rate; oxygen
\end{abstract}

Communicated by Peter Krustrup.

B. Sperlich $(\triangle)$

Integrative and Experimental Training Science, Department of Sport Science, Julius-Maximilians-Universität Würzburg, University of Würzburg, Judenbühlweg 11, 97082 Würzburg, Germany

e-mail: billy.sperlich@uni-wuerzburg.de

B. Sperlich · C. Zinner $\cdot$ H.-C. Holmberg Swedish Winter Sports Research Centre, Department of Health Sciences, Mid Sweden University, 83125 Östersund, Sweden

R. Pfister · G. Michels

Department III of Internal Medicine, University of Cologne,

50937 Cologne, Germany uptake and carbon dioxide production; tissue oxygen saturation; and the lactate concentration, $\mathrm{pH}$, oxygen saturation, level of hemoglobin and hematocrit of the blood were similar under both conditions.

Conclusions Our present findings reveal that four apneas by cyclists prior to a 4-km time trial led to splenic contraction, but no change in mean power output, the level of hemoglobin, hematocrit, oxygen saturation of the m. vastus lateralis or oxygen uptake.

Keywords Breath-hold $\cdot$ Cycling $\cdot$ Hypoxia $\cdot$ Repeated apneas $\cdot$ Spleen contraction

$\begin{array}{ll}\text { Abbreviations } \\ \text { ANOVA } & \text { Analysis of variance } \\ \mathrm{Hb} & \text { Hemoglobin } \\ \mathrm{HbO}_{2} & \text { Oxy-hemoglobin } \\ \mathrm{Hct} & \text { Hematocrit } \\ \mathrm{HHb} & \text { Deoxy-hemoglobin } \\ \mathrm{NIRS}^{\mathrm{N}} & \text { Near-infrared spectroscopy } \\ \mathrm{pCO}_{2} & \text { Partial pressure of carbon dioxide } \\ \mathrm{pO}_{2} & \text { Partial pressure of oxygen } \\ \mathrm{S}_{\mathrm{a}} & \text { Oxygen saturation } \\ \mathrm{TSI}_{2} & \text { Tissue saturation index } \\ \mathrm{TT} & \text { Time trial } \\ \mathrm{VO}_{2 \text { peak }} & \text { Peak oxygen uptake } \\ \mathrm{W} & \text { Watt }\end{array}$

\section{Introduction}

It is well documented that physical performance that is predominantly aerobic in nature [e.g., time trials (TT) in cycling] is highly dependent on oxygen uptake and thus demonstrates close correlation with factors that contribute 
to the availability of oxygen, such as blood volume and level of hemoglobin $(\mathrm{Hb})$ (Abbiss and Laursen 2005; Convertino 1991; Heinicke et al. 2001; Marx and Vergouwen 1998; Warburton et al. 1999). Accordingly, increasing the level of circulating $\mathrm{Hb}$ by e.g., blood transfusion (Buick et al. 1980; Ekblom et al. 1972), hormonal stimulation (Heuberger et al. 2013) or hypoxic training (Schmidt et al. 2002), improves performance in endurance disciplines, especially cycling (Abbiss and Laursen 2005). However, these approaches for augmenting the level of $\mathrm{Hb}$ are illegal, unethical and/or expensive and a simple, socially acceptable and inexpensive ergogenic strategy in this context would be of considerable value to athletes.

In this context, repeated bouts of apnea (i.e., volitional holding of the breath for as long as possible, e.g., 3-5 times with 2-min intervals of recovery within a 10 -min period) has been shown to induce arterial hypoxia, thereby stimulating the spleen to contract (Bakovic et al. 2005; Prommer et al. 2007; Schagatay et al. 2001). This leads, in turn, to immediate elevations in serum levels of erythropoietin (de Bruijn et al. 2008) and $\mathrm{Hb}$ and the hematocrit (Hct) (Bakovic et al. 2005; Schagatay et al. 2001), although there are certain conflicting results with respect to the $\mathrm{Hb}$ concentration (Prommer et al. 2007). For example, during repeated apnea, $\mathrm{Hb}$ and $\mathrm{Hct}$ have been shown to increase, returning to baseline $10 \mathrm{~min}$ afterward (Schagatay et al. 2001). In contrast, however, the serum concentration of erythropoietin (EPO) was elevated 15,12 and $16 \%$ at 1,2 and $3 \mathrm{~h}$ following repeated apnea, respectively, and returning to baseline after $5 \mathrm{~h}$ (de Bruijn et al. 2008).

Thus, the question arises as to whether endurance performance during, for example, a time trial of cycling can be improved by repeated bouts of apnea immediately prior to the trial. To the best of our knowledge, this has never been examined and, therefore, the aim of the present investigation was to test the hypothesis that time trial performance by moderately to well-trained cyclists can be enhanced by repeated maximal voluntary apnea immediately before the start.

\section{Materials and methods}

\section{Subjects}

The seven male cyclists [age: $27.1 \pm 2.1$ years; height: $182.0 \pm 8.5 \mathrm{~cm}$; body mass: $74.8 \pm 9.2 \mathrm{~kg}$; peak oxygen uptake: $56.9 \pm 6.6 \mathrm{~mL} \mathrm{~min}^{-1} \mathrm{~kg}^{-1}$ (mean $\pm \mathrm{SD}$ )] who participated all had extensive experience with the laboratory procedures employed here. Beforehand, each was informed about the protocols and gave his written consent to participate. All procedures were approved by the Ethics Committee of the University of Wuppertal, Germany (on
September 10, 2013) and conducted in accordance with the Declaration of Helsinki.

Test procedures

During the first pre-diagnostic visit, our volunteers performed a step test on a bicycle ergometer to determine their individual $\mathrm{VO}_{2 \text { peak }}$ values. During the second prediagnostic visit, the participants carried out a 4-km time trial at maximal exertion to familiarize themselves with the test procedures employed. On the third occasion, they all performed the actual 4-km time trial, which was repeated 7 days later-in one case with and the other without prior repeated apnea, in randomized order. All were instructed to be adequately hydrated and to refrain from consuming alcohol or caffeine for $24 \mathrm{~h}$ prior to each test.

\section{Main procedures for testing}

After the baseline measurements were taken, each athlete warmed up by cycling for $10 \mathrm{~min}$ at $1.5 \mathrm{~W} \mathrm{~kg}^{-1}$. Thereafter, in a supine position each participant was instructed either to hold his breath for as long as possible four times (with 2-min intervening intervals of rest and no information on the duration of the apneas) or to breathe normally for $15 \mathrm{~min}$. Immediately thereafter, the cyclist got onto the bicycle ergometer, which was then calibrated and the TT program initiated. In addition, proper attachment of all cables and electrodes was re-checked. The time lapse from standing up until initiation of the TT was approximately $30-45 \mathrm{~s}$. Thereafter, each cycled the equivalent of $4 \mathrm{~km}$ at maximal capacity on their own racing bike mounted on a cycle ergometer with electrical braking (Cyclus 2, Avantronic, Leipzig, Germany). The mean power output for this entire effort was obtained using the Cyclus 2 training system software.

$\mathrm{VO}_{2 \text { peak }}$ was determined by pedaling for 3 min with no resistance (baseline), followed by a stepwise increase $\left(30 \mathrm{~W} \mathrm{~min}^{-1}\right)$ in power output accompanied by strong verbal encouragement. The athletes were instructed to pedal at a constant freely chosen frequency $>80 \mathrm{~min}^{-1}$. The test was terminated when the revolutions per minute fell below 65 .

Oxygen uptake was monitored continuously throughout testing with an open circuit breath-by-breath spirograph (Cortex, MetaMax 3B, Leipzig, Germany), employing standard algorithms to compensate for the time delay between gas consumption and the signal. This gas analyzer was calibrated prior to each test using both $15.8 \%$ $\mathrm{O}_{2}$ and $5 \% \mathrm{O}_{2}$ in $\mathrm{N}_{2}$ (Praxair, Düsseldorf, Germany), concentrations encompassing the range of the anticipated fractional concentration of $\mathrm{O}_{2}$. The volume sensor was 


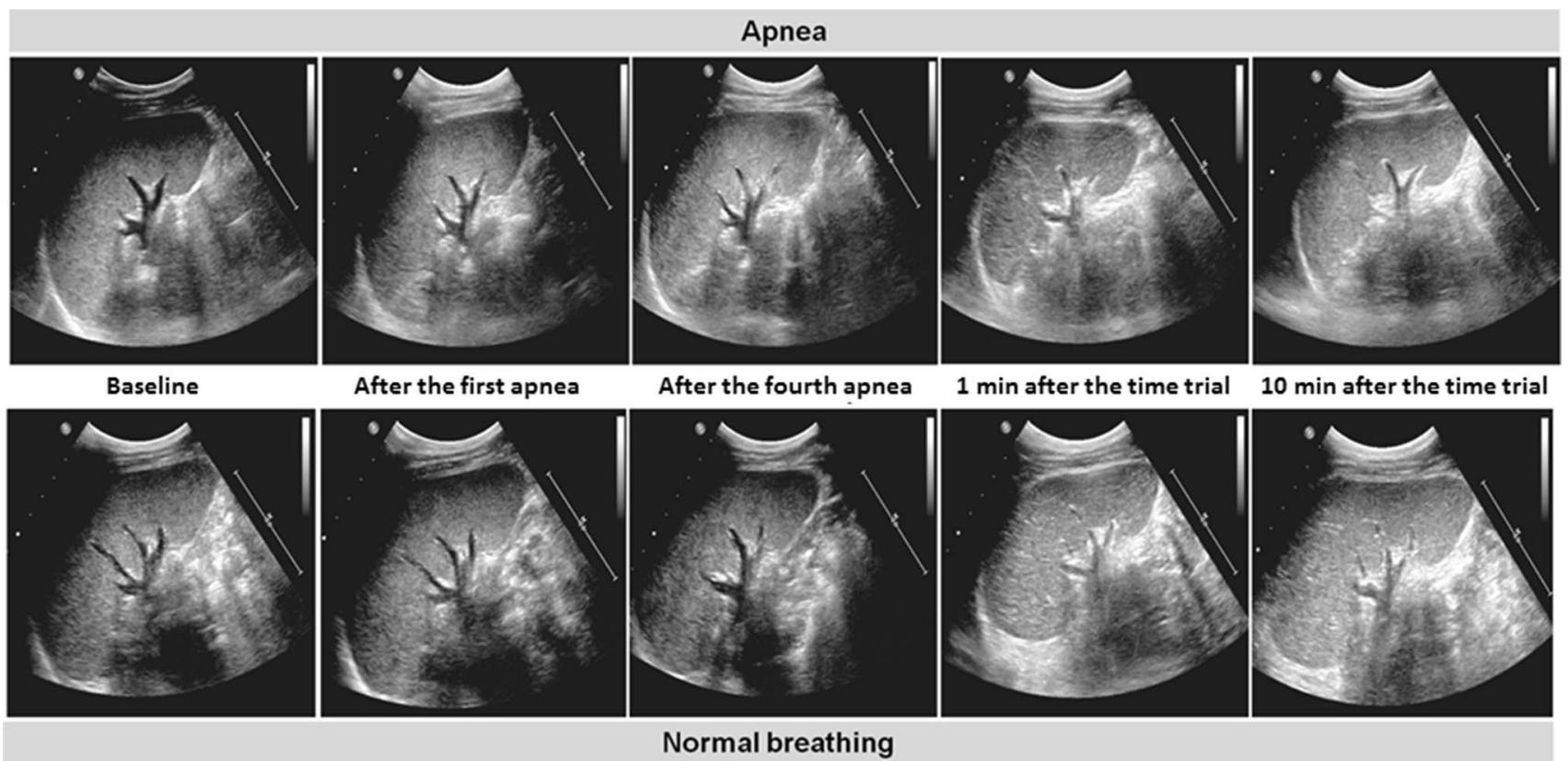

Fig. 1 Ultrasound imaging of the spleen of one of our subjects, either breathing normally or experiencing four bouts of apnea, before and after the $4-\mathrm{km}$ time trial

Table 1 The time required to complete each $\mathrm{km}$ of the 4-km time trial with and without apnea prior (in seconds)

\begin{tabular}{llllll}
\hline Prior breathing & \multicolumn{2}{l}{ Time to complete $(\mathrm{Km})$} & \multicolumn{2}{c}{ Best $P$} \\
\cline { 2 - 5 } & 1st & 2nd & 3rd & 4th & \\
\hline Apnea & $95 \pm 7$ & $185 \pm 11$ & $273 \pm 14$ & $342 \pm 34$ & 0.99 \\
Normal & $88 \pm 6$ & $176 \pm 10$ & $266 \pm 14$ & $326 \pm 68$ & 1.11 \\
\hline
\end{tabular}

calibrated using a precision 3-L syringe (Cortex, Leipzig, Germany). Average respiratory values for 30-s intervals were calculated and the oxygen uptake during the final $30 \mathrm{~s}$ of the step test defined as peak oxygen uptake $\left(\mathrm{VO}_{2 \text { peak }}\right)$. One minute prior to warm-up, baseline respiratory values were determined with the cyclist sitting on the bike. The values pre-warm-up, during the seventh minute of warm-up and 9 min after the TT were subjected to statistical analysis.

Blood samples $(200 \mu \mathrm{L})$ were collected from the left earlobe into capillary tubes (safeCLINITUBE capillary, Radiometer Medical, Brønshøj, Denmark) for determination of lactate, $\mathrm{pH}$, oxygen saturation $\left(\mathrm{S}_{\mathrm{a}} \mathrm{O}_{2}\right)$ and partial pressure of oxygen $\left(\mathrm{pO}_{2}\right)$ and carbon dioxide $\left(\mathrm{pCO}_{2}\right)$ (ABL800 FLEX blood gas analyzer, Radiometer Medical, Brønshøj, Denmark). Capillary blood was sampled at baseline, after the first and fourth bout of apnea, and immediately and $10 \mathrm{~min}$ after the TT.

Following implantation of an 18-gauge peripheral venous catheter (Introcan Safety ${ }^{\circledR}$, B. Braun Melsungen AG, Melsungen, Germany), venous blood (7.4 ml) was collected from the right cubital vein using the Sarstedt ${ }^{\circledR}$ blood collection system (Sarstedt AG \& Co, Nümbrecht, Germany) for determination of albumin, total protein, $\mathrm{Hb}$, Hct and the numbers of red and white blood cells and thrombocytes. These samples were taken at baseline and after the first and fourth bouts of apnea, as well as immediately and $10 \mathrm{~min}$ after the time trial. All blood analyses were carried out with a Cobas ${ }^{\circledR} 8000$ chemistry analyzer (Roche Diagnostics, Germany) and a Sysmex ${ }^{\circledR}$ XE-5000 fully automated hematology analyzer (Sysmex, Singapore) at the Institute for Clinical Chemistry (University Hospital of Cologne, Cologne, Germany).

Heart rate, measured using the Infinity ${ }^{\circledR}$ monitoring system VF7 (Draeger Medical Systems, Telford, PA, USA), was averaged every $5 \mathrm{~s}$ and the highest value obtained defined as peak heart rate.

Tissue levels of oxy- $\left[\mathrm{HbO}_{2}\right]$ and deoxy- $[\mathrm{HHb}]$ hemoglobin were monitored with a portable near-infrared spectrophotometer (NIRS; wavelengths:760-840 nm; Portamon, Artinis Medical System, Zetten, the Netherlands) 
attached with a $10 \times 10$-cm adhesive patch across the widest girth of the left vastus lateralis muscle, as described previously (Sperlich et al. 2013). A marker allowed accurate repositioning of the sensor for each subsequent trial. The tissue saturation index (TSI, calculated as $\left[\mathrm{HbO}_{2}\right] /$ $\left(\left[\mathrm{HbO}_{2}\right]+[\mathrm{HHb}]\right) \times 100$ and expressed as $\left.\%\right)$ provided an indicator of the balance between oxygen supply and consumption. Previous findings have demonstrated that this value reflects muscle oxygenation more accurately than [HHb] (Buchheit and Ufland 2011; Wolf et al. 2007). The TSI values observed at and after baseline, during warm-up, after the first and during the fourth session of apnea, during the first and final minutes of the time trial, and immediately and $10 \mathrm{~min}$ after this trial were subjected to statistical analysis.

Furthermore, the maximal longitudinal length and transversal width of the spleen of each participant were determined at baseline, after the first and fourth apneas, and 1 and $10 \mathrm{~min}$ after the time trial using ultrasound imaging (Philips Healthcare iE33 Ultrasound System with a C5-2 curved array transducer; Philips, Hamburg, Germany). The images were obtained in the left lateral position and the cross-sectional area of the spleen calculated as described previously (Hurford et al. 1996; Koga 1979). All sonographic measurements were performed by the same physician highly experienced in abdominal ultrasonography.

\section{Statistical analyses}

Calculation by conventional procedures provided the mean values and standard deviations (SD) for all sets of data. Testing revealed that all of the data were normally distributed, so that there was no need for further transformation. The effect size, Cohen's $d$ (Cohen 1988), was calculated for all parameters, with the thresholds for small, moderate and large effects set at $0.20,0.50$ and 0.80 , respectively (Cohen 1988). Repeated-measures ANOVA were applied to compare each variable during the two different trials and at different time points. When a global difference over time was indicated, Fisher post hoc analysis was used to determine when the change occurred. An alpha of $P<0.05$ was considered to be statistically significant and all analyses were carried out with the Statistica software package for Windows ${ }^{\circledR}$ (version 7.1, StatSoft Inc., Tulsa, OK, USA).

\section{Results}

The mean $( \pm \mathrm{SD})$ power output during the 4-km time trial was similar with $(293 \pm 48 \mathrm{~W})$ and without $(305 \pm 42 \mathrm{~W})$ prior apnea $(P=0.11, d=0.27)$, and there was no difference in the time required to complete each kilometer (Table 1).

The mean $( \pm \mathrm{SD})$ durations of the four bouts of apnea were $76.4 \pm 30.0,115 \pm 35.9,128 \pm 41.8$ and $140 \pm 45.7$ s, respectively. Figure 1 illustrates the volume of the spleen of one of our cyclists at various time points.

As shown in Table 2, the spleen was reduced in size after the fourth bout of apnea, as well as one and $10 \mathrm{~min}$ after the subsequent time trial, while with normal breathing the spleen was smaller one and $10 \mathrm{~min}$ after the time trial. All cardiorespiratory and hemodynamic parameters, as well as the characteristics of capillary and venous blood at the various time points, are documented in Tables 3, 4, 5. Except for significantly higher oxygen uptake, carbon dioxide production and minute ventilation following the first bout of apnea than with normal breathing, no differences were detected.

\section{Discussion}

The present study was designed to test the hypothesis that the time trial performance of moderately to well-trained cyclists can be enhanced by repeated maximal voluntary apnea immediately prior to the test. The major findings were that although repeated holding of the breath for as long as possible before a 4-km time trial led to splenic contraction, the level of $\mathrm{Hb}$ and hematocrit, oxygen saturation in the m. vastus lateralis, and oxygen uptake and mean power output were all the same as with normal breathing.

Following repeated bouts of apnea, the volume of the spleen in divers (Hurford et al. 1990; Prommer et al. 2007) and seals is reduced (Hurford et al. 1996). The decrease of approximately $10 \%$ from baseline to the first bout of apnea observed here is similar to previously reported values ranging from 20 to $46 \%$ (Bakovic et al. 2005; Balestra et al. 2006; Espersen et al. 2002; Ge et al. 2002; Prommer et al. 2007; Schagatay et al. 2005). However, our subjects were not exposed to cold water and immersion of the face in cold water enhances the "diving reflex" (Foster and Sheel 2005) and might thereby also amplify splenic contraction in connection with hypoxia. In addition, in contrast to earlier investigations, our athletes were not specifically trained in the performance of apneic maneuvers (Espersen et al. 2002; Ge et al. 2002).

Elevations in the level of $\mathrm{Hct}, \mathrm{Hb}$ and erythropoietin following splenic contraction induced by a series of apneas have been documented in healthy humans previously (Bakovic et al. 2005; de Bruijn et al. 2008; Richardson et al. 2005; Schagatay et al. 2001). However, here we found no changes in $\mathrm{Hb}$ or Hct following the repeated bouts of apnea, in agreement with the lack of any change in $\mathrm{Hb}$ concentration during training of apnea or in scuba 


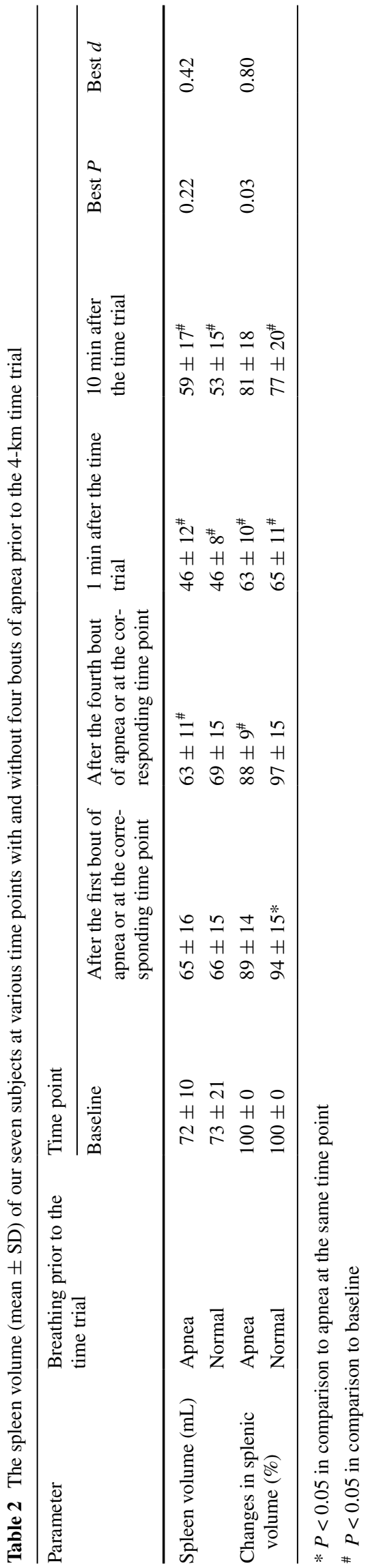

divers (Prommer et al. 2007). As mentioned earlier (Schagatay et al. 2001), acute responses to repeated apnea might be influenced by training status, the period of time during which the breath is held or the time at which blood samples are taken. For example, Schagatay et al. (2001) found that the elevated levels of Hct and $\mathrm{Hb}$ declined 3 min after the last apnea and returned to baseline after $10 \mathrm{~min}$.

In the present study, the length of the apneas varied between participants and our subjects had no training in apneic maneuvers beforehand, which may indicate differences in psychological tolerance to holding the breath, as well as explain why the level of $\mathrm{Hb}$ and Hct remained constant. Furthermore, elevations in the level of $\mathrm{Hb}$ and Hct following apnea are most pronounced in individuals subjected frequently to apnea, such as divers, suggesting that such increases may be promoted by long-term repeated apnea (Richardson et al. 2005).

Our NIRS data indicate that at least at the site of measurement, oxygenation of the vastus lateralis muscle was the same following repeated apnea and normal breathing. As discussed previously (Yamada et al. 2005), oxygenation of human skeletal muscle reflects the balance between oxygen supply and utilization (Chance et al. 1992; Hamaoka et al. 1996), so we cannot exclude possible counterbalancing alterations in both of these factors. However, on the basis of the NIRS findings, we conclude that repeated apnea did not influence oxygenation of the vastus lateralis muscle, which may explain, at least in part, why the TT performance was similar to that following conventional breathing.

Oxygen uptake and the blood level of lactate are informative parameters, since the supply of oxygen to working muscles is considered to be a limiting factor with respect to performance (Astrand and Rodahl 1986; Faude et al. 2009). Both of these parameters, as well as the heart rate and respiratory exchange ratio, were uninfluenced by the type of breathing. The NIRS measurements reflect the local balance between oxygen supply and utilization (Chance et al. 1992; Hamaoka et al. 1996), which, in turn, provides an integrated indicator of oxidative metabolism. Here, we detected no alterations in the level of $\mathrm{Hb}, \mathrm{Hct}, \mathrm{O}_{2}$ saturation of the m. vastus lateralis and oxygen uptake due to prestart apnea. Consequently, we conclude that the capacity for storage of oxygen and carbon dioxide was not enhanced by repeated apnea and did not result in higher muscular power output during the 4-km time trial.

Our present findings regarding acute responses to repeated bouts of apnea do not allow conclusions as to whether apnea during several weeks of training might enhance performance. Indeed, some evidence indicates improved peak and submaximal performance following long-term apnea training by swimmers, due to augmentation of maximal oxygen uptake, arterial oxygen saturation and respiratory compensation (Lemaitre et al. 2009). 
Table 3 The cardiorespiratory and hemodynamic responses (mean \pm SD) of our seven cyclists at various time points with and without four bouts of apnea prior to the 4-km time trial

\begin{tabular}{|c|c|c|c|c|c|c|c|c|c|}
\hline \multirow[t]{2}{*}{ Parameter } & \multirow{2}{*}{$\begin{array}{l}\text { Breathing } \\
\text { prior to the } \\
\text { time trial }\end{array}$} & \multicolumn{8}{|l|}{ Time point } \\
\hline & & Baseline & Warm-up & $\begin{array}{l}\text { After the first } \\
\text { bout of apnea } \\
\text { or at the cor- } \\
\text { responding time } \\
\text { point }\end{array}$ & $\begin{array}{l}\text { First min of the } \\
\text { time trial }\end{array}$ & $\begin{array}{l}\text { Last minute of } \\
\text { the time trial }\end{array}$ & $\begin{array}{l}10 \text { min after } \\
\text { the time trial }\end{array}$ & Best $P$ & Best $d$ \\
\hline \multirow[t]{2}{*}{ Heart rate } & Apnea & $73 \pm 12$ & $144 \pm 13.3$ & $85 \pm 8$ & $170 \pm 11$ & $185 \pm 3$ & $104 \pm 5$ & 0.20 & 0.55 \\
\hline & Normal & $76 \pm 16$ & $151 \pm 12.9$ & $82 \pm 14$ & $171 \pm 7$ & $189 \pm 4$ & $100 \pm 7$ & & \\
\hline \multirow{2}{*}{$\begin{array}{l}\text { Oxygen uptake } \\
\left(\mathrm{mL} \mathrm{kg}^{-1} \mathrm{~min}^{-1}\right)\end{array}$} & Apnea & $362 \pm 44$ & $2370 \pm 184$ & $1450 \pm 409 *$ & $3400 \pm 565$ & $4120 \pm 811^{*}$ & $475 \pm 90$ & $<0.001$ & 3.66 \\
\hline & Normal & $382 \pm 62$ & $2310 \pm 389$ & $369 \pm 84$ & $3450 \pm 455$ & $3800 \pm 666$ & $505 \pm 67$ & & \\
\hline \multirow{2}{*}{$\begin{array}{l}\text { Carbon dioxide } \\
\text { production } \\
\left(\mathrm{mL} \mathrm{kg}^{-1} \min ^{-1}\right)\end{array}$} & Apnea & $526 \pm 575$ & $2031 \pm 410$ & $1290 \pm 411^{*}$ & $3490 \pm 930$ & $4640 \pm 994$ & $444 \pm 97$ & $<0.001$ & 3.13 \\
\hline & Normal & $536 \pm 571$ & $2132 \pm 316$ & $364 \pm 85$ & $3540 \pm 687$ & $4260 \pm 852$ & $462 \pm 47$ & & \\
\hline \multirow{2}{*}{$\begin{array}{l}\text { Respiratory } \\
\text { exchange ratio } \\
\text { (RER) }\end{array}$} & Apnea & $0.84 \pm 0.14$ & $0.93 \pm 0.09$ & $1.11 \pm 0.22$ & $1.02 \pm 0.18$ & $1.12 \pm 0.05$ & $0.93 \pm 0.08$ & 0.26 & 1.04 \\
\hline & Normal & $0.83 \pm 0.16$ & $0.93 \pm 0.05$ & $0.94 \pm 0.07$ & $1.05 \pm 0.14$ & $1.12 \pm 0.05$ & $0.92 \pm 0.08$ & & \\
\hline \multirow{2}{*}{$\begin{array}{l}\text { Breathing frequency } \\
\left(\mathrm{L} \mathrm{min}^{-1}\right)\end{array}$} & Apnea & $20 \pm 6$ & $24 \pm 7$ & $22 \pm 6$ & $36 \pm 6$ & $56 \pm 10$ & $20 \pm 6$ & 0.22 & 0.76 \\
\hline & Normal & $18 \pm 2$ & $26 \pm 4$ & $18 \pm 3$ & $34 \pm 4$ & $57 \pm 11$ & $23 \pm 4$ & & \\
\hline \multirow{2}{*}{$\begin{array}{l}\text { Minute ventilation } \\
\left(\mathrm{L} \min ^{-1}\right)\end{array}$} & Apnea & $12 \pm 3$ & $57 \pm 15$ & $45 \pm 17 *$ & $104 \pm 26.6$ & $170 \pm 31.5$ & $20 \pm 6$ & $<0.001$ & 2.60 \\
\hline & Normal & $12 \pm 3$ & $61 \pm 12$ & $14 \pm 3$ & $103 \pm 18.1$ & $160 \pm 26.7$ & $21 \pm 3$ & & \\
\hline \multirow{2}{*}{$\begin{array}{l}\text { Tissue saturation } \\
\text { index }(\%)\end{array}$} & Apnea & $78 \pm 5$ & $64 \pm 12 *$ & $79 \pm 3$ & $59 \pm 11$ & $57 \pm 12$ & $79 \pm 3$ & 0.004 & 0.40 \\
\hline & Normal & $76 \pm 3$ & $68 \pm 7$ & $79 \pm 3$ & $61 \pm 9$ & $58 \pm 9$ & $78 \pm 2$ & & \\
\hline
\end{tabular}

$* P<0.05$ in comparison to normal breathing at the same time point

Table 4 The characteristics of capillary blood (mean \pm SD) of our seven cyclists at various time points with and without four bouts of apnea prior to the 4-km time trial

\begin{tabular}{|c|c|c|c|c|c|c|c|c|}
\hline Parameter & $\begin{array}{l}\text { Breathing prior } \\
\text { to the time trial }\end{array}$ & Baseline & $\begin{array}{l}\text { After the first } \\
\text { bout of apnea }\end{array}$ & $\begin{array}{l}\text { After the fourth } \\
\text { bout of apnea }\end{array}$ & $\begin{array}{l}\text { Immediately } \\
\text { after time trial }\end{array}$ & $\begin{array}{l}10 \text { min after the } \\
\text { time trial }\end{array}$ & Best $P$ & Best $d$ \\
\hline \multirow{2}{*}{$\begin{array}{l}\text { Lactate } \\
\qquad\left(\mathrm{mmol} \mathrm{L}^{-1}\right)\end{array}$} & Apnea & $1.5 \pm 0.7$ & $1.3 \pm 0.4$ & $1.6 \pm 1.4$ & $14.6 \pm 1.9$ & $12.8 \pm 2.8$ & \multirow[t]{2}{*}{0.69} & \multirow[t]{2}{*}{1.24} \\
\hline & Normal & $1.2 \pm 0.3$ & $2.5 \pm 1.2$ & $1.6 \pm 0.5$ & $15.5 \pm 2.2$ & $12.5 \pm 3.8$ & & \\
\hline \multirow[t]{2}{*}{$\mathrm{pH}$} & Apnea & $7.40 \pm 0.06$ & $7.41 \pm 0.06$ & $7.45 \pm 0.07$ & $7.16 \pm 0.10^{*}$ & $7.21 \pm 0.09 *$ & \multirow[t]{2}{*}{0.04} & \multirow[t]{2}{*}{0.95} \\
\hline & Normal & $7.40 \pm 0.04$ & $7.38 \pm 0.03$ & $7.41 \pm 0.04$ & $7.23 \pm 0.03$ & $7.28 \pm 0.06$ & & \\
\hline \multirow{2}{*}{$\begin{array}{l}\text { Oxygen saturation } \\
(\%)\end{array}$} & Apnea & $98 \pm 01$ & $98 \pm 1$ & $99 \pm 0$ & $96 \pm 2$ & $97 \pm 0$ & \multirow[t]{2}{*}{0.27} & \multirow[t]{2}{*}{0.62} \\
\hline & Normal & $98 \pm 0$ & $98 \pm 1$ & $98 \pm 0$ & $96 \pm 1$ & $97 \pm 1$ & & \\
\hline \multirow{2}{*}{$\begin{array}{l}\text { Partial pressure of } \\
\mathrm{O}_{2}(\mathrm{mmHg})\end{array}$} & Apnea & $89 \pm 12$ & $103 \pm 18$ & $98 \pm 5$ & $101 \pm 13$ & $101 \pm 6$ & \multirow[t]{2}{*}{0.70} & \multirow[t]{2}{*}{0.73} \\
\hline & Normal & $97 \pm 9$ & $101 \pm 7$ & $98 \pm 4$ & $102 \pm 10$ & $101 \pm 3$ & & \\
\hline \multirow{2}{*}{$\begin{array}{l}\text { Partial pressure of } \\
\mathrm{CO}_{2}(\mathrm{mmHg})\end{array}$} & Apnea & $39 \pm 2$ & $36 \pm 2$ & $33 \pm 4^{*}$ & $30 \pm 4$ & $29 \pm 2$ & \multirow[t]{2}{*}{0.04} & \multirow[t]{2}{*}{1.19} \\
\hline & Normal & $38 \pm 2$ & $36 \pm 2$ & $37 \pm 3$ & $30 \pm 1$ & $28 \pm 2$ & & \\
\hline
\end{tabular}

* $P<0.05$ in comparison to normal breathing at the same time point

Finally, long-term apnea training may also promote enhanced performance by improving the buffer capacity of muscles, thereby attenuating blood acidosis and post-apnea oxidative stress (Joulia et al. 2002, 2003). However, only future research will reveal whether such training can also improve the performance of athletes competing on land. 
Table 5 Characteristics of the venous blood (mean \pm SD) of our seven cyclists at various time points with or without four bouts of apnea prior to the 4-km time trial

\begin{tabular}{|c|c|c|c|c|c|c|c|c|}
\hline \multirow[t]{2}{*}{ Parameter } & \multirow{2}{*}{$\begin{array}{l}\text { Breathing prior to } \\
\text { the time trial }\end{array}$} & \multicolumn{7}{|l|}{ Time point } \\
\hline & & Baseline & $\begin{array}{l}\text { After the first } \\
\text { bout of apnea }\end{array}$ & $\begin{array}{l}\text { After the fourth } \\
\text { bout of apnea }\end{array}$ & $\begin{array}{l}\text { Immediately after } \\
\text { the time trial }\end{array}$ & $\begin{array}{l}10 \text { min after the } \\
\text { time trial }\end{array}$ & Best $P$ & Best $d$ \\
\hline \multirow[t]{2}{*}{ Albumin $\left(\mathrm{g} \mathrm{dL}^{-1}\right)$} & apnea & $47 \pm 2$ & $49 \pm 1$ & $47 \pm 2$ & $53 \pm 1$ & $50 \pm 2$ & 0.27 & 0.46 \\
\hline & normal & $48 \pm 1$ & $49 \pm 1$ & $47 \pm 1$ & $54 \pm 1$ & $50 \pm 1$ & & \\
\hline \multirow{2}{*}{$\begin{array}{l}\text { Total plasma pro- } \\
\text { tein }\left(\mathrm{g} \mathrm{dL}^{-1}\right)\end{array}$} & apnea & $72 \pm 2$ & $74 \pm 2$ & $70.7 \pm 2.9$ & $81.9 \pm 2.9$ & $74.9 \pm 3.6$ & 0.22 & 0.36 \\
\hline & normal & $73 \pm 2$ & $75 \pm 2$ & $70.7 \pm 1.6$ & $81.9 \pm 1.6$ & $75.7 \pm 2.6$ & & \\
\hline \multirow{2}{*}{$\begin{array}{l}\text { Red blood cells } \\
\quad\left(10^{6} \mu \mathrm{L}^{-1}\right)\end{array}$} & apnea & $4.7 \pm 0.4$ & $4.8 \pm 0.4$ & $4.8 \pm 0.5$ & $5.2 \pm 0.4$ & $4.8 \pm 0.4^{*}$ & 0.03 & 0.28 \\
\hline & normal & $4.8 \pm 0.2$ & $4.9 \pm 0.3$ & $4.7 \pm 0.2$ & $5.2 \pm 0.3$ & $4.9 \pm 0.3$ & & \\
\hline \multirow{2}{*}{$\begin{array}{l}\text { Hemoglobin } \\
\left(\mathrm{g} \mathrm{dL}^{-1}\right)\end{array}$} & apnea & $14.3 \pm 1.1$ & $14.5 \pm 1.2$ & $14.3 \pm 1.4$ & $15.8 \pm 1.3$ & $14.6 \pm 1.3$ & 0.14 & 0.39 \\
\hline & normal & $14.5 \pm 0.7$ & $14.9 \pm 0.8$ & $14.3 \pm 0.7$ & $15.4 \pm 1.4$ & $14.9 \pm 0.8$ & & \\
\hline \multirow[t]{2}{*}{ Hematocrit (\%) } & apnea & $41.0 \pm 2.8$ & $41.9 \pm 3.4$ & $41.3 \pm 3.5$ & $46.9 \pm 4.0$ & $43.0 \pm 3.8$ & 0.22 & 0.27 \\
\hline & normal & $41.3 \pm 2.4$ & $42.4 \pm 2.6$ & $40.6 \pm 2.4$ & $47.1 \pm 2.5$ & $43.9 \pm 2.8$ & & \\
\hline \multirow{2}{*}{$\begin{array}{l}\text { White blood cells } \\
\qquad\left(10^{3} \mu \mathrm{L}^{-1}\right)\end{array}$} & apnea & $7.0 \pm 2.5$ & $7.9 \pm 3.4$ & $6.8 \pm 2.8$ & $11.6 \pm 4.1$ & $10.2 \pm 4.6$ & 0.40 & 0.11 \\
\hline & normal & $6.8 \pm 2.3$ & $7.6 \pm 2.3$ & $6.7 \pm 2.0$ & $12.0 \pm 2.9$ & $10.3 \pm 3.3$ & & \\
\hline \multirow{2}{*}{$\begin{array}{l}\text { Thrombocytes } \\
\left(10^{3} \mu \mathrm{L}^{-1}\right)\end{array}$} & apnea & $221 \pm 36$ & $234 \pm 50$ & $221 \pm 46$ & $244 \pm 48$ & $247 \pm 61$ & 0.13 & 0.18 \\
\hline & normal & $224 \pm 55$ & $237 \pm 58$ & $217 \pm 56$ & $253 \pm 53$ & $253 \pm 67$ & & \\
\hline
\end{tabular}

$* P<0.05$ in comparison to normal breathing at the same time point

\section{Conclusion}

In conclusion, the present investigation reveals that repeated maximal voluntary apnea prior to a $4-\mathrm{km}$ time trial leads to splenic contraction, but no change in the level of $\mathrm{Hb}$ and $\mathrm{Hct}$, saturation of the m. vastus lateralis with oxygen, oxygen uptake or mean power.

Acknowledgments The authors extend their sincere thanks to Dr. Thomas Streicher for help with the laboratory analyses and to Dr. Christian Keller for technical help.

Conflict of interest None of the authors has any conflicts of interest to declare.

\section{References}

Abbiss CR, Laursen PB (2005) Models to explain fatigue during prolonged endurance cycling. Sports Med 35:865-898

Astrand P-O, Rodahl K (1986) Textbook of work physiology :physiological bases of exercise, 3rd edn. McGraw Hill, New York

Bakovic D, Eterovic D, Saratlija-Novakovic Z, Palada I, Valic Z, Bilopavlovic N, Dujic Z (2005) Effect of human splenic contraction on variation in circulating blood cell counts. Clin Exp Pharmacol Physiol 32:944-951. doi:10.1111/j.1440-1681.2005.04289.x

Balestra C, Germonpre P, Poortmans JR, Marroni A (2006) Serum erythropoietin levels in healthy humans after a short period of normobaric and hyperbaric oxygen breathing: the "normobaric oxygen paradox". J Appl Physiol 100:512-518. doi:10.1152/jap plphysiol.00964.2005

Buchheit M, Ufland P (2011) Effect of endurance training on performance and muscle reoxygenation rate during repeated-sprint running. Eur J Appl Physiol 111:293-301. doi:10.1007/ s00421-010-1654-9

Buick FJ, Gledhill N, Froese AB, Spriet L, Meyers EC (1980) Effect of induced erythrocythemia on aerobic work capacity. J Appl Physiol: Respir, Environ Exerc Physiol 48:636-642

Chance B, Dait MT, Zhang CD, Hamaoka T, Hagerman F (1992) Recovery from exercise-induced desaturation in the quadriceps muscles of elite competitive rowers. Am J Physiol 262:C766-C775

Cohen D (1988) Statistical power analysis for the behavioral sciences. 2nd (edn) Lawrence Erlbaum Associates, Hillsdale, NJ

Convertino VA (1991) Blood volume: its adaptation to endurance training. Med Sci Sports Exerc 23:1338-1348

de Bruijn R, Richardson M, Schagatay E (2008) Increased erythropoietin concentration after repeated apneas in humans. Eur J Appl Physiol 102:609-613. doi:10.1007/s00421-007-0639-9

Ekblom B, Goldbarg AN, Gullbring B (1972) Response to exercise after blood loss and reinfusion. J Appl Physiol 33:175-180

Espersen K, Frandsen H, Lorentzen T, Kanstrup IL, Christensen NJ (2002) The human spleen as an erythrocyte reservoir in divingrelated interventions. J Appl Physiol (1985) 92:2071-2079. doi:1 0.1152/japplphysiol.00055.2001

Faude O, Kindermann W, Meyer T (2009) Lactate threshold concepts: how valid are they? Sports Med 39:469-490. doi:10.2165/00007256-200939060-00003

Foster GE, Sheel AW (2005) The human diving response, its function, and its control. Scand J Med Sci Sports 15:3-12. doi:10.1111/j.1600-0838.2005.00440.x

Ge RL et al (2002) Determinants of erythropoietin release in response to short-term hypobaric hypoxia. J Appl Physiol (1985) 92:23612367. doi:10.1152/japplphysiol.00684.2001

Hamaoka T et al (1996) Noninvasive measures of oxidative metabolism on working human muscles by near-infrared spectroscopy. $\mathrm{J}$ Appl Physiol 81:1410-1417

Heinicke $\mathrm{K}$ et al (2001) Blood volume and hemoglobin mass in elite athletes of different disciplines. Int J Sports Med 22:504-512. doi :10.1055/s-2001-17613 
Heuberger JA et al (2013) Erythropoietin doping in cycling: lack of evidence for efficacy and a negative risk-benefit. Br J Clin Pharmacol 75:1406-1421. doi:10.1111/bcp.12034

Hurford WE, Hong SK, Park YS, Ahn DW, Shiraki K, Mohri M, Zapol WM (1990) Splenic contraction during breath-hold diving in the Korean Ama. J Appl Physiol 69:932-936

Hurford WE et al (1996) Splenic contraction, catecholamine release, and blood volume redistribution during diving in the Weddell seal. J Appl Physiol (1985) 80:298-306

Joulia F, Steinberg JG, Wolff F, Gavarry O, Jammes Y (2002) Reduced oxidative stress and blood lactic acidosis in trained breath-hold human divers. Respir Physiol Neurobiol 133:121-130

Joulia F, Steinberg JG, Faucher M, Jamin T, Ulmer C, Kipson N, Jammes Y (2003) Breath-hold training of humans reduces oxidative stress and blood acidosis after static and dynamic apnea. Respir Physiol Neurobiol 137:19-27

Koga T (1979) Correlation between sectional area of the spleen by ultrasonic tomography and actual volume of the removed spleen. J Clin Ultrasound 7:119-120. doi:10.1002/jcu.1870070208

Lemaitre F, Seifert L, Polin D, Juge J, Tourny-Chollet C, Chollet D (2009) Apnea training effects on swimming coordination. J Strength Cond Res/Natl Strength Cond Assoc 23:1909-1914. doi :10.1519/JSC.0b013e3181b073a8

Marx JJ, Vergouwen PC (1998) Packed-cell volume in elite athletes. Lancet 352:451

Prommer N, Ehrmann U, Schmidt W, Steinacker JM, Radermacher P, Muth CM (2007) Total haemoglobin mass and spleen contraction: a study on competitive apnea divers, non-diving athletes and untrained control subjects. Eur J Appl Physiol 101:753-759. doi:10.1007/s00421-007-0556-y
Richardson M, de Bruijn R, Holmberg HC, Bjorklund G, Haughey H, Schagatay E (2005) Increase of hemoglobin concentration after maximal apneas in divers, skiers, and untrained humans. Can J Appl Physiol 30:276-281

Schagatay E, Andersson JP, Hallen M, Palsson B (2001) Selected contribution: role of spleen emptying in prolonging apneas in humans. J Appl Physiol (1985) 90:1623-1629 (discussion 1606)

Schagatay E, Haughey H, Reimers J (2005) Speed of spleen volume changes evoked by serial apneas. Eur J Appl Physiol 93:447-452. doi:10.1007/s00421-004-1224-0

Schmidt W et al (2002) Blood volume and hemoglobin mass in endurance athletes from moderate altitude. Med Sci Sports Exerc 34:1934-1940. doi:10.1249/01.MSS.0000041225.34124.98

Sperlich B, Born DP, Swaren M, Kilian Y, Geesmann B, KohlBareis M, Holmberg HC (2013) Is leg compression beneficial for alpine skiers? BMC sports sci, med rehabil 5:18. doi:10.1186/2052-1847-5-18

Warburton DE, Gledhill N, Jamnik VK, Krip B, Card N (1999) Induced hypervolemia, cardiac function, $\mathrm{VO}_{2} \mathrm{max}$, and performance of elite cyclists. Med Sci Sports Exerc 31:800-808

Wolf M, Ferrari M, Quaresima V (2007) Progress of near-infrared spectroscopy and topography for brain and muscle clinical applications. J Biomed Opt 12:062104. doi:10.1117/1.2804899

Yamada E et al (2005) Vastus lateralis oxygenation and blood volume measured by near-infrared spectroscopy during whole body vibration. Clin Physiol Funct Imaging 25:203-208. doi:10.1111/j.1475-097X.2005.00614.x 